\title{
Sustainability teaching using case-based debates
}

\author{
Panikos Georgallis and Kayleigh Bruijn \\ Amsterdam Business School, University of Amsterdam, \\ Amsterdam, The Netherlands
}

\begin{abstract}
Purpose - Given today's pressing societal challenges, business schools are increasingly expected to incorporate sustainability in their curricula. Yet, while research on corporate sustainability is on the rise, there is less innovation in teaching methods as most institutions rely on traditional methods to teach sustainability in the classroom. This paper aims to present the case-based debate as an appropriate teaching method for exposing students to the complexity of business sustainability issues.

Design/methodology/approach - The pedagogical background of the traditional case method and the debate method have been analyzed to provide an integrated understanding of the benefits of combining the two in the case-based debate. Building on the authors' experiences from using case-based debates in the classroom, the paper describes what a case-debate is and how it can be implemented.

Findings - The paper offers a practical tool that can be used to teach sustainability in business schools and other educational institutions. Case-based debates can elicit active participation, support the development of students' critical thinking skills and improve reflexivity by compelling students to seriously and actively engage with opposing viewpoints on a given issue.

Originality/value - This paper presents a hybrid approach for sustainability teaching that combines the benefits of the traditional case method with those of an in-class debate. The case-based debate method has received little attention in educational research and business sustainability teaching practice but can serve multiple teaching objectives relevant to sustainability teaching.
\end{abstract}

Keywords Sustainability, Grand challenges, Sustainability teaching, Case method, Debate method, Case-based debates

Paper type Case study

\section{Introduction}

Pressing sustainability challenges threaten our economies and societies. Issues such as climate change and the deterioration of ecological systems have negative impacts on human health, species extinction, agricultural yields, freshwater availability and the erosion or inundation of coastal areas (IPCC, 2021). Often classified as grand challenges - complex, unsolved global problems that are important for human, ecological and societal well-being -

(C) Panikos Georgallis and Kayleigh Bruijn. Published by Emerald Publishing Limited. This article is published under the Creative Commons Attribution (CC BY 4.0) licence. Anyone may reproduce, distribute, translate and create derivative works of this article (for both commercial and noncommercial purposes), subject to full attribution to the original publication and authors. The full terms of this licence may be seen at http://creativecommons.org/licences/by/4.0/legalcode

The authors would like to thank Dr Arno Kourula as well as participants at the Best Teaching Practices session of the 19th ABIS Annual Colloquium for their help and comments. We also thank the students of the Business Strategy and Sustainability course at the University of Amsterdam who offered feedback and helped improve this teaching method over time. The first author also acknowledges the support of the Dutch Research Council (NWO) (Veni grant 016-195-232).
Received 31 March 2021 Revised 9 September 2021 Accepted 30 November 2021 
JIEB

15,1

sustainability issues cannot be solved by one actor alone. Rather, the speed and scale of changes required to address these issues are so far-reaching that they must involve unprecedented action from multiple parties (Lee et al., 2022). And while governments are seen as responsible for addressing collective problems and civil society has often taken the lead in addressing sustainability challenges, business is also an important actor for achieving sustainability. Economic activity is responsible for much of the rise in environmental and atmospheric pollution in recent decades, signifying the responsibility of business for sustainability challenges. Moreover, with the list of top economic entities on our planet including more corporations than countries (Global Justice Now, 2018), business is arguably the most powerful institution on Earth - and therefore, a fundamental tool for the much-needed sustainability transition.

Given the responsibility and power of business to address sustainability challenges, what is the role of higher education institutions that train, nurture and develop future business leaders? Most business schools did not incorporate sustainability in their curricula until at least the turn of the century; and even when they did, social and environmental issues were considered peripheral topics within business school education (Augustine and King, 2019; Jack, 2020a). This, however, is changing. We are currently in the midst of a transition in business education, both in terms of the centrality of sustainability as a topic and in terms of the demand for business, schools to integrate sustainability in their curricula (Hoffman, 2017; Dyllick and Muff, 2020). Driven by a broader societal push for developing responsible future leaders who will act as agents for good (El Hajj et al., 2017; Lilley et al., 2014), third-party institutions and accreditation bodies have also started to urge business schools to adopt sustainability programs and courses (Hoffman, 2017; Landrum and Ohsowski, 2017). For instance, in 2007, the UN founded the Principles for Responsible Management Education (PRME), an initiative that aims to "realize the Sustainable Development Goals through responsible management education" and that involves over 850 signatories and partners from all over the world (PRME, 2021). In 2013, the European Quality Improvement System established standards for integrating ethics, responsibility and sustainability into business school teaching as part of its accreditation criteria. And in 2016, the Association to Advance Collegiate Schools of Business created social and environmental sustainability standards that accredited institutions are required to adopt. Most recently, in response to criticism against rankings by media organizations, such as the Financial Times, alternative rankings and ratings that heavily weigh the incorporation of sustainability into curricula are being developed (Pitt-Watson and Quigley, 2019). All in all, the need for teaching sustainability in business schools is clearly there, and so is the demand - with sustainability becoming a key selling point for MBA and other management programs aiming to attract students (Klecha, 2017; Scott, 2015).

Material to teach sustainability has also become more widely available. Corporate sustainability research, once at the fringes of organizational scholarship, has now moved mainstream. The number of academic articles on sustainability in management research have increased exponentially in recent years (Williams et al., 2017), and sustainability has made its way into canonical management research on business strategy, organizational behavior, operations, marketing, accounting and finance (Bansal and Hoffman, 2012). A recent study featured in the Financial Times (Jack, 2020b) shows that the share of journal articles related to the UN sustainable development goals is on the rise among triple-crown business schools as well as other institutions.

Despite clear demand and availability of content, however, research suggests that most institutions rely on traditional teaching methods to teach sustainability in business schools (Godemann et al., 2011; Landrum and Ohsowski, 2017). Defined in line with the "triple 
bottom line" concept (Elkington, 1997), corporate sustainability reflects the need for companies to simultaneously reconcile the social, environmental and economic performance of the organization (Alhaddi, 2015; Bansal, 2005; Scherer et al., 2013). However, traditional teaching methods may not be ideal to capture such complexity as they often imply a treatment of sustainability as "enterprise integration" (Hoffman, 2017, 2018): the recognition of sustainability as a business issue that can be (re)framed to fit with core business approaches. Per this view, overexploitation of natural resources may translate into an issue of resource availability relevant for corporate procurement and production processes; activist scrutiny in response to unethical business conduct may translate into a reputational issue relevant for public relations; and the reinvention of agricultural practices, such as organic, local or fair-trade food may translate into an issue of responding to "green" demand relevant for marketers. Framing sustainability in "business as usual" terms, however, may not be enough to help future business leaders realize the fundamental market transformations required to address the most pressing sustainability challenges of our time.

Corporate sustainability issues are, at their core, systemic and can rarely be reduced to classic strategy, marketing or operational problems. They tend to be complex, dispersed, global and interdependent, and as a consequence, they are characterized by greater ambiguity and uncertainty with regard to the potency and consequences of any particular action (Lee et al., 2022). As the triple bottom line concept implies, sustainability issues tend to involve paradoxes and trade-offs between the needs of different stakeholders (Van der Byl and Slawinski, 2015); they require the appreciation of cultural complexity (Lilley et al., 2014); and often, they unearth discrepancies between social, environmental and financial objectives (Friedland and Jain, 2020). Correspondingly, scholars have argued that teaching sustainability to business students should focus on advancing their understanding of both the complex nature and the different viewpoints of the topic (Kearins and Springett, 2003) by following a pedagogical approach that is rooted in experiential and active learning, critical thinking, reflexivity and problem-solving (Springett, 2005; Kalamas Hedden et al., 2017).

This article presents one approach to incorporating the complexity of sustainability issues into the classroom: the case-based debate. Combining the advantages of case-based teaching with those of an in-class debate, case-based debates elicit active participation in the classroom, contribute to the development of students' practical and critical thinking skills and improve their reflexivity by compelling students to consider the multiple viewpoints of the case. Therefore, case-based debates are especially suitable for sustainability teaching as this practice exposes students to the complexity of corporate sustainability issues and prompts them to actively engage with these complexities. Our aim with this article is to offer a practical tool that educators can imitate, modify and improve to more effectively teach sustainability in business schools. Thus, the primary emphasis is on the practice of casebased debates. Below we briefly discuss the pedagogical background and then elaborate on what a case-debate is and how it can be implemented, building on the authors' experiences from applying it. Finally, we conclude with a broader discussion of the benefits and applicability of the method, as well as limitations and opportunities for future research.

\section{Background}

A variety of teaching methods have been used to educate business students, including but not limited to lectures and tutorials, debates, simulations, role-playing, the case method and site-visits (Brown and Guilding, 1993). Each teaching method serves its own purpose. For instance, lectures help students obtain specific information and knowledge that constitutes the first step in cognitive learning; and simulations benefit students' interpersonal and problem-solving skills (Farashahi and Tajeddin, 2018). Considering that sustainability 
JIEB

15,1

teaching requires an experiential and active learning approach that fosters critical thinking, reflexivity and problem-solving skills (Springett, 2005; Kalamas Hedden et al., 2017), there are various teaching methods available such as role play and site-visits (Collins and Kearins, $2007,2010)$. Here our aim is to highlight one particular approach, namely, the case-based debate.

As we will argue below, the advantages of this method render it very suitable for teaching sustainability-related courses. Yet, it has received scarce attention in educational research (Austin and Packard, 2009; Doran et al, 2011) and teaching practice (see Appendix for further details). We present the method and its usefulness for sustainability teaching in Sections 3 and 4. Before elaborating on the practice of case-based debates, we first discuss, in this section, the pedagogical background of the two teaching techniques it relies on: the case method and the debate method.

\subsection{Case-based teaching}

Case-based teaching can take many forms, but it usually refers to the case discussion that was prescribed as a dominant teaching approach at the Harvard Business School in the mid1900s (Dooley and Skinner, 1977; Greiner et al., 2003). A case discussion is an "interactive, student-centered exploration of realistic and specific narratives" (Boehrer and Linsky, 1990, p. 42), and consists of multiple stages. First, the teacher assigns a case to the students. Next, the students are expected to prepare and analyze the case before class. During class, the students discuss with each other both how the case is understood and the different paths of action (Carlson and Velenchik, 2006).

To explain the case discussion, Boehrer and Linsky (1990) use the metaphor of the case as a story, a vehicle and an event. First, a case can be classified as a story because it presents, in a narrative form, the details of a complex real-world situation confronting a practitioner (Garvin, 2003). Second, a case can be seen as a vehicle for bringing practical problems into the classroom (Farashahi and Tajeddin, 2018) and for eliciting interactions and deep discussions among students. Third, a case is ultimately an event, in that the value of a case depends on what students make of it during the discussion.

Three main principles underlying case-based teaching help explain how this method can benefit the learning experience of the majority of students. First, case-based teaching helps students acquire and develop practical skills by providing them the opportunity to apply what they have learned to an actual business problem (Garvin, 2003). Teaching students both to know and to act contributes to the development of skills that are crucial for them to understand and deal with complex situations in the world of practice (Barnes et al., 1994). Furthermore, accomplished practitioners usually acquire their skills through experiencing a wide variety of business problems (Boehrer and Linsky, 1990). Given that learning through experience positively contributes to the development of practical skills, case-based teaching can bring this practical experience to the classroom (Garvin, 2007). Thus, case-based teaching diminishes the distance between theory and practice. This is an important teaching objective since one central aim of business schools is to prepare students for their professional careers.

Second, case-based teaching prepares students for practice by familiarizing them with the complexity that can be expected on the job. By working through a case, students are required to deal with several constraints, such as incomplete information, conflicts between values and objectives, a mismatch between needs and resources and most importantly, the fact that there is oftentimes not a single right answer to the problem at hand (Radi Afsouran et al., 2018; Ray, 2018). In turn, this develops students' ability to deal with uncertain situations (Blumenthal, 1991), fosters their analytical and critical thinking skills (Pilz and Zenner, 2018) and allows them to gain confidence that they can handle business problems 
under complex constraints (Boehrer and Linsky, 1990). Furthermore, since there is usually not one right answer, a good case discussion focuses on the process by which a decision is made and includes the evaluation of different options, contributing to the development of reasoning skills (Ambrosini et al., 2010).

Finally, case-based teaching reallocates the focus from the teacher to the students by expecting them to be at the center of the discussion. Specifically, students are expected to participate by presenting their ideas, asking questions and building on the statements of other students as well as challenging them (Barnes et al., 1994). In a good case discussion, students interact actively with one another through challenging and questioning each other's assertions. This contributes to students learning from each other. As such, the focus is on the students; the teacher's role is to facilitate and structure the discussion. This changes the role of the student from passively absorbing knowledge to actively engaging in discussion and decision-making. As a result, case-based teaching has the potential to elicit active engagement and learning.

\subsection{The debate method}

While case-based teaching can positively contribute to learning, its ultimate success depends on the motivation of the students to be involved in the casework and actively participate in the discussion. One educational tool that has been found to foster motivation and energy is the debate (Stewart and Winn, 1996). As with case-based teaching, debating has become an accepted educational method in a variety of disciplines (Vo and Morris, 2006).

Debating consists of "reasoned arguments for or against a proposition" (Huryn, 1986, p. 266). The traditional debate format involves multiple phases starting with both the supporting and opposing teams presenting and introducing their arguments. This is followed by rebuttals, where the debaters get the chance to respond to the other team's viewpoints. The use of debates can be beneficial for a variety of reasons, which include enhancing motivation, critical thinking skills and students' understanding of different viewpoints on a particular issue (Argyropoulou, 2021; Schroeder and Ebert, 1983).

First, debates have been found to create environments that motivate active engagement during and after the debate (Cariñanos-Ayala et al., 2021; Green and Klug, 1990; Winsted, 2010). As students are required to respond to the arguments of their classmates, they feel the need to exert more effort and prepare well themselves. This competitive spirit can generate energy and enthusiasm during the debate (Stewart and Winn, 1996), and students are oftentimes enthusiastic about debates because it is seen as a break from the routine of conventional teaching methods (Vo and Morris, 2006). Because debates enhance students' motivation to be involved, this educational method positively contributes to students' engagement with the course materials, rendering debates an effective strategy for stimulating active learning (Kennedy, 2007).

Second, an important prerequisite for active learning is engagement with higher-order thinking. Higher-order thinking consists of the following tasks: analysis, synthesis and evaluation (Bonwell and Eison, 1991). To perform well, debaters closely examine relevant information, integrate ideas and arguments and finally provide an evaluation (Vo and Morris, 2006). Thus, the debate method promotes students' active engagement with materials as well as higher-order thinking. In fact, the debate method has been found to be among the best teaching methods to stimulate critical thinking and increases students' confidence in their public speaking skills (Combs and Bourne, 1989; Rodriguez-Dono and Hernández-Fernández, 2021). By having to assess and critique arguments of the opposing team, the method gives students the opportunity to practice professional disagreeing. Being able to respectfully address points of disagreement and strongly advocating one's own position will be useful in students' professional business careers (Stewart and Winn, 1996). 
JIEB

15,1

Scholars have also shown that students felt debates increased their critical thinking because they stimulated them to thoroughly consider multiple positions on issues (Hennessey, 2014), making debates particularly useful in courses that focus on the interplay between business and society (Schroeder and Ebert, 1983). Teaching such courses is complex as they often involve questions that do not have a universally agreed-upon answer. Thus, multiple perspectives on controversial questions and issues tend to be presented.

This brings us to the final benefit of using the debate method which is that it stimulates students' understanding of opposing positions on complex and controversial matters. The method forces students to go beyond their own viewpoints because they might be asked to defend a position that they oppose or because they need to anticipate opponent's arguments. This leaves students no choice but to thoroughly analyze and examine contrasting positions (Schroeder and Ebert, 1983). All in all, debates can prove useful in setting students free from established viewpoints and stimulate them to appreciate complexity.

\section{The practice of case-based debates: process and organization}

A case-based debate is a combination of the traditional case method with an in-class debate and aims to benefit from the advantages of each. Scholars analyzing case-based learning have argued that complementing the case method with an in-class debate can facilitate higher levels of student participation as the debate aspect enhances student reflection in terms of questioning and advocating a specific line of action (Austin and Packard, 2009). Some research has also found that complementing the case method with an in-class debate results in a high-quality of case analysis (Doran et al., 2011). Specifically, we expect that in the context of business sustainability teaching, case-based debates can serve at least the following learning objectives: students learn to appreciate how the inherent complexity of sustainability manifests in practice; reflect on and analyze different viewpoints on sustainability problems and solutions, and articulate a position in a compelling and convincing manner.

In this section, our goal is to describe how the method can be applied based on the authors' experience in practicing the case-based debate method in a Business Strategy and Sustainability course. As context, consider that this is an elective graduate (Masters-level) course that is usually given to groups of approximately 30 students. The learning objectives are summarized in Figure 1 (the case-based debate aligns mostly with learning objectives 2, 4 and 5). Other teaching methods used during this course include interactive lectures that are focused on introducing literature and initiating discussions and a company project that tries to simulate a real-world environment where students develop a business solution to sustainability challenges for a particular company. Concerning the case-based debates, the following process assumes a workshop-style class format that runs through multiple sessions but can be adjusted for other formats.

Before each class: Prior to the class (typically several days or weeks before), students are separated into an even number of teams. For instance, for a class with three workshops, six teams are needed; for a class with five workshops, 10 teams are needed; and so on. For each of these sessions, the class is pre-assigned a case that relates to sustainability in a business or other organization. The case may describe the organization's sustainability strategy in general, its approach on a specific sustainability issue such as climate change or diversity or a narrower topic such as a managerial decision about a specific sustainability initiative.

Together with the case, the instructor also assigns a specific statement and a counterstatement that argues for the exact opposite. These statements can be products of the case, but they can also be related without being direct derivatives [1]. For instance, a case about a specific organization facing pressure to divest from fossil fuels (Hoffman, 2020) may 


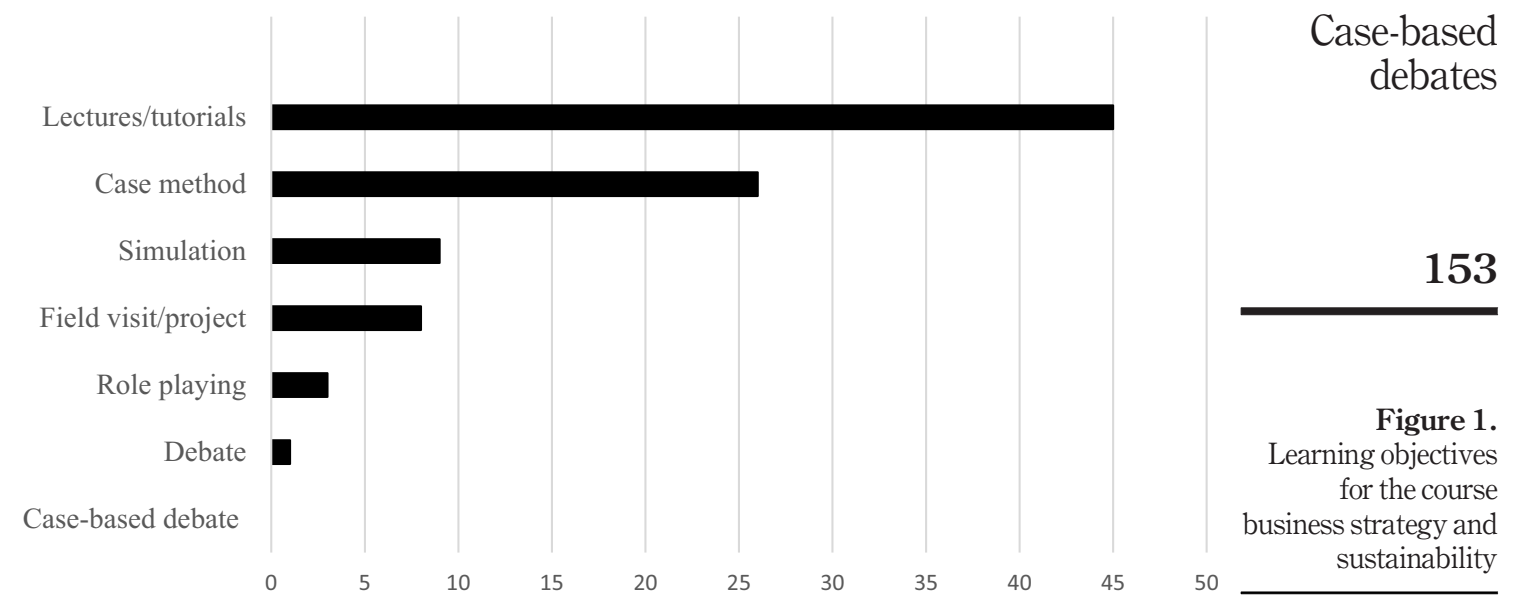

inspire debate statements about that particular organization ("university X should (not) divest from fossil fuels by year Y") or about a broader issue or question ("universities should (not) divest from fossil fuels"; "all publicly funded organizations should (not) divest from fossil fuels"). What is important is that the case provides the context and thick description that is relevant for the debate question without answering that question. This is typical of cases related to sustainability, as the complexity and associated trade-offs involved are rarely amenable to one obvious and straightforward answer but rather call for multiple interpretations and viewpoints from stakeholders.

Two teams are assigned to debate during each session, and all other teams are assigned as "jury." Prior to the class, the debating teams are asked to prepare to discuss the dilemma and take a position in favor of (first team) or against (second team) the debate statement. In other words, the teams are pre-assigned their position. To prepare, students are instructed to read the case and statement carefully, as well as the literature that is covered in the course and that relates to the topic. They are also encouraged to seek additional material if it is useful for their teams' argument and to anticipate the opposing team's arguments so that they can respond during class. Finally, because in-class debates can be stressful for students and making real-time decisions is hard, teams are instructed to arrange roles in advance (who speaks first, second, etc) and create a plan for how to approach the recess and rebuttals. This is particularly important for online sessions where spontaneous coordination is challenging.

The "jury" teams (all teams not debating in that session) are also expected to read the case and statement carefully, as well as the literature covered in that class session. They are asked to pre-assign one student (or more) to take notes, and one person as the team's main communicator for the session. That person will facilitate asking questions and provide feedback on behalf of the team during and after the session. Note that debating and jury teams rotate with each session so that all teams get the opportunity to debate during the course of the entire class.

Table 1 includes an example of a case-based debate and Table 2 showcases a practical example of an "instruction manual" for how students can prepare.

During class: A recommended approach is to start the session with an overview of the case by the instructor. This should be brief and focusing mainly on the facts of the case to serve as a reminder of the dilemmas or complexities involved. The role of the case is 
Darwinians at the gate: sustainability, innovation and growth at $D S M *$

Theoretical

Session topic perspectives Case description Debate statements Learning objectives

\section{4}

This session aims to explore the link between

sustainability and profitability, i.e. does it pay to be green?

Table 1.

Example case for a case-based debate: Royal DSM
- Creating Previously a stateshared value (Porter and Kramer, 2011)

- Strategic CSR (Vishwanathan et al., 2020)

- Shape of the CSR-CFP relationship (Barnett and Salomon, 2012)

\section{owned coal} mining company, Royal DSM transitioned into a multinational Life and Material

Sciences company. Royal DSM has made continuous efforts to embed sustainability in its values and practices, going beyond merely complying with regulation. To further ensure the continuity of the company, the next transition may require becoming a truly sustainable company, one where sustainability is fully integrated and contributes visibly to profitability. That being said, can sustainability be a key driver of further improving profitability for Royal DSM in the future?

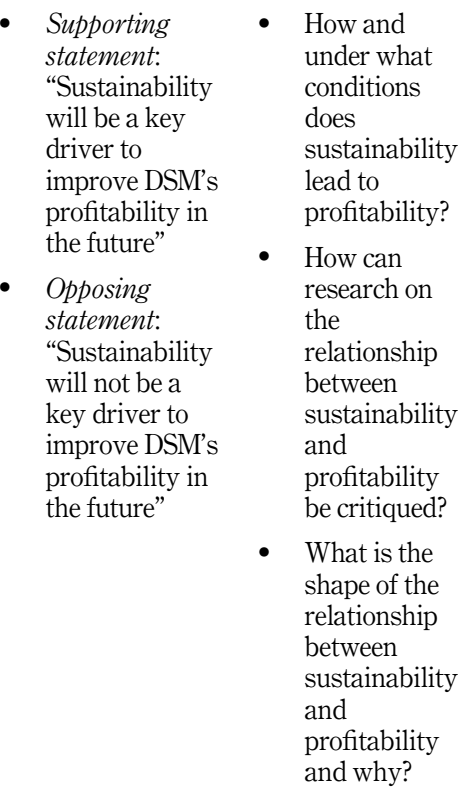
Note: CSR = Corporate social responsibility; CFP = corporate financial performance
*Source: Leleux and Van Der Kaaij (2013)

mainly to provide context in advance of the debate, so contrary to a typical case teaching approach, it is important not to get into the argumentation as this might bias the class in favor of or against the debate statement. Once the facts are given as a reminder to the class, the debate follows. We offer below suggestions for how to organize the debate, acknowledging, however, that the format of the debate can vary substantially. We also include further practical suggestions regarding timelines and the role of different teams in Table 3. 


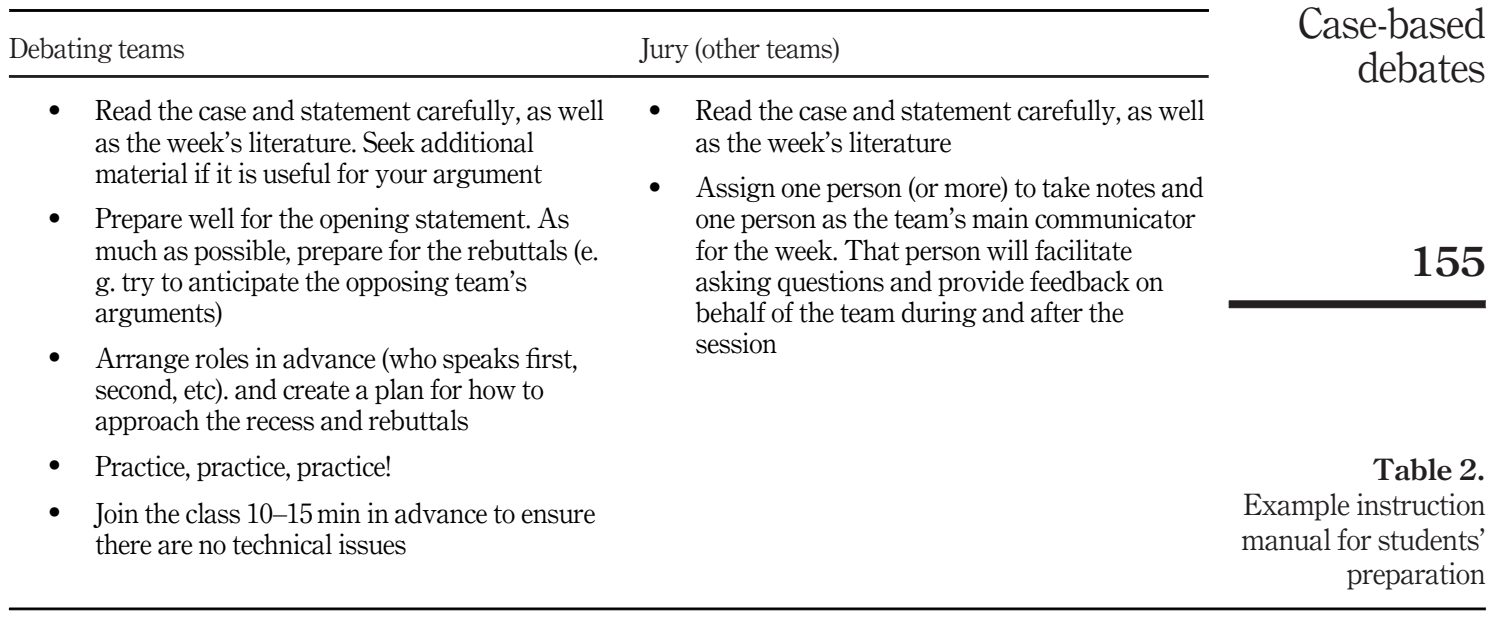

The first stage of the debate consists of the two debating teams taking turns to present their opening statements. Then, they are given time (a recess) to prepare for a rebuttal. During that time, the jury teams discuss and prepare questions and comments [2]. The second stage includes two rounds of rebuttals, intercepted by one recess that has a similar function as the first one. The third stage is a Question and Answer session, where the jury teams direct their questions toward the two debating teams. Next, the jury (all non-debating students) choose, based on prescribed criteria, a winning team by anonymous voting. While not necessary, the opportunity to vote offers students ownership of the situation and allows for "fun" competition between the two teams. Finally, the session ends with the jury and the instructor providing developmental feedback to the debating teams.

After class: All jury teams are asked to provide peer evaluations to each of the debating teams. These are then assembled, anonymized and sent by the instructor or a teaching assistant to the teams. The instructor also offers separate feedback in two forms: First, specific feedback, including the grades, is sent to the two debating teams. Second, feedback with general lessons learnt (regarding the case or the learning objectives, argumentation, evidentiary basis, rhetorical style, etc). is sent by the instructor to the entire class.

\section{Discussion}

The case-based debate is a method that may offer several advantages (Doran et al., 2011) relevant for teaching sustainability in business schools or other educational institutions. Building on the case method and the debate method, it has the potential to combine the best of both worlds. We outline these benefits below and then consider limitations and future research opportunities.

\subsection{Benefits and recommendations}

At the most abstract level, this method combines the thickness of cases with the stimulating nature of debates to improve student experience and learning. One of the main advantages 


\section{JIEB 15,1}

\section{Table 3.}

Debate schedule example

\begin{tabular}{|c|c|c|c|c|}
\hline & & & the opposing & \\
\hline Recess & $10 \mathrm{~min}$ & $\begin{array}{l}\text { Prepare response to } \\
\text { the other team's } \\
\text { arguments }\end{array}$ & $\begin{array}{l}\text { statement } \\
\text { Prepare response to } \\
\text { the other team's } \\
\text { arguments }\end{array}$ & $\begin{array}{l}\text { Prepare slides with } \\
\text { questions and } \\
\text { comments for the two } \\
\text { teams }\end{array}$ \\
\hline Rebuttal 1 & $3-5 \min$ & $\begin{array}{l}\text { Present critique to } \\
\text { other team's } \\
\text { arguments }\end{array}$ & & \\
\hline & $3-5 \min$ & & $\begin{array}{l}\text { Present critique to } \\
\text { other team's } \\
\text { arguments }\end{array}$ & \\
\hline Recess & $5 \min$ & $\begin{array}{l}\text { Prepare for second } \\
\text { rebuttal }\end{array}$ & $\begin{array}{l}\text { Prepare for second } \\
\text { rebuttal }\end{array}$ & $\begin{array}{l}\text { Update comments/ } \\
\text { questions }\end{array}$ \\
\hline Rebuttal 2 & $2 \min$ & $\begin{array}{l}\text { Present critique and/ } \\
\text { or conclude }\end{array}$ & & \\
\hline & $2 \min$ & & $\begin{array}{l}\text { Present critique and/ } \\
\text { or conclude }\end{array}$ & \\
\hline Recess & $5 \mathrm{~min}$ & & & $\begin{array}{l}\text { Update comments/ } \\
\text { questions }\end{array}$ \\
\hline$Q \& A$ & $10-15 \mathrm{~min}$ & $\begin{array}{l}\text { Answer jury } \\
\text { questions }\end{array}$ & $\begin{array}{l}\text { Answer jury } \\
\text { questions }\end{array}$ & $\begin{array}{l}\text { Pose questions to the } \\
\text { two teams }\end{array}$ \\
\hline $\begin{array}{l}\text { Winner selection and } \\
\text { feedback }\end{array}$ & $15-20 \mathrm{~min}$ & & & $\begin{array}{l}\text { Vote for winning } \\
\text { team and provide } \\
\text { feedback to both } \\
\text { teams** }\end{array}$ \\
\hline
\end{tabular}

\begin{tabular}{llll}
\hline Stage & Time* $^{*}$ & Supporting team & Opposing team \\
\hline Opening statements & $5-10 \mathrm{~min}$ & $\begin{array}{l}\text { Present the main } \\
\text { arguments to defend } \\
\text { the supporting } \\
\text { statement }\end{array}$
\end{tabular}

Present main arguments to defend the opposing statement the other team's questions and comments for the two teams questions two teams Vote for winning teams***

Note: *Timelines are indicative and can be adjusted depending on the learning objectives and class duration. **Note that feedback is given by teams, but voting is individual

of the case method is that the detailed description of a practical situation helps diminish the gap between theory and practice. Students are immersed in comprehensive and grounded information stemming from real-life situations and get to practice their reasoning and decision-making skills. Debates can serve a similar purpose in that the engagement and lively discussion that they elicit allow students to engage in higher-order thinking. Yet, they go one step further. Contrary to the traditional case method, students get to "own" a practical position and are much more involved as they are interested in winning the debate. Moreover, students are now required to reason from multiple viewpoints, as they need to anticipate opponents' arguments to prepare for the debate, and the competitive element brings additional motivation and enthusiasm to the task.

Combining the two methods using case-based debates allows the class to spend less time on discussing the details of the case (which students can read in advance), and more time on the way forward. The emphasis is, therefore, on the argumentation - using theory and evidence - behind the statement of the debate. Thus, it is important for instructors to ensure that all students come to class prepared and are 
participating, even those not debating. This can be encouraged in a number of ways. First, Professors can assign study groups that meet before class to discuss the case (Boehrer and Linsky, 1990) or present students with a "social contract" that explains the importance of preparing and participating (Shapiro, 1984). Second, they can elicit participation (and indirectly preparation) by cold-calling (Dallimore et al., 2013). Third, they can complement the debate discussion with role-playing (cf. Boehrer and Linsky, 1990; Dean and Fornaciari, 2002), whereby students are asked questions like "how would you argue for this position" or "what evidence would you mount to oppose this statement." Given that debating teams are naturally motivated and more likely to prepare, these strategies are more relevant for non-debating teams. Thus, an effective way to stimulate non-debating teams is to assign them as "jury," as described above. Giving them responsibility for engaging with the debating teams during a $Q \& A$, feedback sessions and ultimately the selection of the debate winner makes the practice stimulating for other teams too, and urges students to prepare and actively participate.

Two additional elements are important for effective execution of this method. First, students are positively predisposed to it as they see it as refreshing break from routine teaching methods, but one disadvantage is that the method is more complicated compared to both the case method and debates. Thus, it is critical for instructors to set very clear expectations for how students can prepare before class and what they need to do during class (see Table 2 for an example). Second, while between-team arguments during the debate and discussion bring out the complexity of business sustainability practice, it is also valuable to have diversity in perspectives within teams. Diversity allows student teams to consider and evaluate multiple viewpoints, which is an important component of decisionmaking in sustainability contexts where multiple stakeholders are involved. Moreover, the growing cultural and international diversity in workplace contexts requires the development of leaders who are able to lead diverse workforces (Crossman and Bordia, 2008; Lilley et al., 2014). To sensitize business students to diverse viewpoints, it is recommended that the debate teams are assigned in a way that maximizes cultural, racial and gender diversity.

\subsection{Limitations and future research opportunities}

Like any other teaching method, case-based debates are not free of limitations. First, the method is quite complex and requires detailed preparation on the part of teachers as well as students. While it can work well in elective courses that most students select out of genuine intellectual curiosity, it is unlikely to be effective in large mandatory classes where many students do not have an intrinsic motivation to engage with the topic. Second, it is a method that aims to develop students' analytical and critical thinking skills as well as reasoning and persuasion abilities; these require higher-order thinking (Bonwell and Eison, 1991) and may not be appropriate for classes at the lower levels of Bloom's taxonomy where the main learning objectives are to understand basic facts and concepts (Bloom, 1956). Future research can investigate which settings and educational levels this method is best suited for, and how it can be combined with more traditional methods such as lectures or cases to enhance student learning.

Future research can also examine the limits of case-based debates and differences in student experience and learning following the application of this method in the classroom. As with classic case teaching, we suggest that this method facilitates learning for a large range of students (Ertmer et al., 1996), although admittedly the evidence is anecdotal (but see Doran et al., 2011). A systematic investigation is beyond 
the scope of this article, yet it is certainly warranted that future research examines overall learning benefits. It would also be useful to investigate differences in the benefits accrued compared to other methods; and the benefits for different student profiles - as individuals can differ extensively in their learning experiences, preferences and styles.

Finally, we discussed case-based debates as relevant for addressing business sustainability topics, but this method is likely applicable to other topics as well. The reasons why it is useful for teaching business sustainability can provide guidance on its generalizability. Sustainability issues in business are characterized by controversy, trade-offs between stakeholder needs or company objectives (Van der Byl and Slawinski, 2015; Friedland and Jain, 2020) and greater complexity and uncertainty regarding decisions and outcomes (Lee et al., 2022; Georgallis et al., 2021). These elements render case-based debates relevant because they elevate the need to understand a practical case and to engage with it by adopting different, often opposing, viewpoints. By extension, the method might be appropriate for the study of other subjects with similar characteristics. Examples can include topics that deal with morality in business and markets (Georgallis and Lee, 2020; Sandel, 2013), courses at the intersection of management and engineering that deal with grand challenges beyond sustainability, and more broadly, interdisciplinary or boundary spanning courses (Fernando et al., 2020).

\section{Conclusion}

At a time when sustainability is high on the agenda of decision-makers in companies, nongovernmental organizations and government agencies, it is paramount that future managers are educated in sustainability topics. This article highlights the case-based debate as one relevant method for teaching sustainability in business schools and other higher education institutions. The case-based debate benefits from combining the advantages of the case method with those of an in-class debate. Specifically, we posit that case-based debates have the potential to contribute to students' practical skills, active participation, critical thinking and reflexivity - as they urge students to consider the complex nature of and multiple viewpoints on sustainability issues.

Building on the authors experiences in applying the method, this article aimed at offering a practical tool for business sustainability educators interested in implementing the case-based debate. We have described the benefits of this method, how it can be executed in the classroom and provided recommendations for practice. We hope this will inspire further application and encourage other educators to reuse, modify and improve the method with the ultimate goal of preparing future leaders to tackle the most pressing sustainability challenges of our times.

\section{Notes}

1. For this reason, there is no need to develop teaching cases tailored to a debate. Instead, instructors can use one of many existing cases that deal with sustainability topics, insofar as they can come up with an interesting debate question/statement that helps achieve the learning objectives.

2. Jury team students tend to be more engaged if this task is concrete (e.g. there is a document they need to fill out) rather than abstract (e.g. "think about comments and questions").

3. http://one.aom.org/ourlibrary

4. https://www.ideasworthteachingawards.com/ 


\section{References}

Alhaddi, H. (2015), "Triple bottom line and sustainability: a literature review", Business and Management Studies, Vol. 1 No. 2, pp. 6-10.

Ambrosini, V., Bowman, C. and Collier, N. (2010), "Using teaching case studies for management research”, Strategic Organization, Vol. 8 No. 3, pp. 206-229.

Argyropoulou, E. (2021), “Can 'debate' transform teaching and learning in higher education?", European Journal of Education and Pedagogy, Vol. 2 No. 3, pp. 178-185.

Augustine, G. and King, B.G. (2019), "Worthy of debate: discursive coherence and agreement in the formation of the field of sustainability in higher education", Socio-Economic Review, Vol. 17 No. 1, pp. 135-165.

Austin, M.J. and Packard, T. (2009), “Case-based learning: educating future human service managers", Journal of Teaching in Social Work, Vol. 29 No. 2, pp. 216-236.

Bansal, P. (2005), "Evolving sustainably: a longitudinal study of corporate sustainable development", Strategic Management Journal, Vol. 26 No. 3, pp. 197-218.

Bansal, P. and Hoffman, A.J. (2012), The Oxford Handbook of Business and the Natural Environment, Oxford University Press, Oxford.

Barnes, L.B., Christensen, C.R. and Hansen, A.J. (1994), Teaching and the Case Method: Text, Cases, and Readings, Harvard Business Press, Boston, MA.

Barnett, M.L. and Salomon, R.M. (2012), "Does it pay to be really good? Addressing the shape of the relationship between social and financial performance", Strategic Management Journal, Vol. 33 No. 11, pp. 1304-1320.

Bloom, B.S. (1956), Taxonomy of Educational Objectives, Vol.1: Cognitive Domain, McKay, New York, NY.

Blumenthal, J. (1991), "Use of the case method in MBA education", Performance Improvement Quarterly, Vol. 4 No. 1, pp. 5-13.

Boehrer, J. and Linsky, M. (1990), "Teaching with cases: learning to question”, New Directions for Teaching and Learning, Vol. 1990 No. 42, pp. 41-57.

Bonwell, C.C. and Eison, J.A. (1991), "Active learning: creating excitement in the classroom", ASHEERIC Higher Education Report No. 1, George Washington University, Washington, DC.

Brown, R.B. and Guilding, C. (1993), "A survey of teaching methods employed in university business school accounting courses”, Accounting Education, Vol. 2 No. 3, pp. 211-218.

Cariñanos-Ayala, S., Arrue, M., Zarandona, J. and Labaka, A. (2021), "The use of structured debate as a teaching strategy among undergraduate nursing students: a systematic review”, Nurse Education Today, Vol. 98, p. 104766.

Carlson, J.A. and Velenchik, A. (2006), "Using the case method in the economics classroom", in Becker, W.E., Becker S.R. and Watts, M.W. (Eds), Teaching Economics: More Alternatives to Chalk and Talk, Edward Elgar, Cheltenham, pp. 59-74.

Collins, E. and Kearins, K. (2007), "Exposing students to the potential and risks of stakeholder engagement when teaching sustainability: a classroom exercise", Journal of Management Education, Vol. 31 No. 4, pp. 521-540.

Collins, E.M. and Kearins, K. (2010), "Delivering on sustainability's global and local orientation", Academy of Management Learning and Education, Vol. 9 No. 3, pp. 499-506.

Combs, H.W. and Bourne, G. (1989), "The impact of marketing debates on oral communication skills", The Bulletin of the Association for Business Communication, Vol. 52 No. 2, pp. 21-25.

Crossman, J. and Bordia, S. (2008), "Emerging issues in international education in business contexts", Journal of International Education in Business, Vol. 1 No. 1, pp. 2-14.

Dallimore, E.J., Hertenstein, J.H. and Platt, M.B. (2013), "Impact of cold-calling on student voluntary participation”, Journal of Management Education, Vol. 37 No. 3, pp. 305-341. 
Dean, K.L. and Fornaciari, C.J. (2002), "How to create and use experiential case-based exercises in a management classroom”, Journal of Management Education, Vol. 26 No. 5, pp. 586-603.

Dooley, A.R. and Skinner, W. (1977), "Casing casemethod methods", The Academy of Management Review, Vol. 2 No. 2, pp. 277-289.

Doran, J., Healy, M., McCutcheon, M. and O'Callaghan, S. (2011), "Adapting case-based teaching to large class settings: an action research approach", Accounting Education, Vol. 20 No. 3, pp. 245-263.

Dyllick, T. and Muff, K. (2020), "A positive impact rating for business schools: case study", Sustainability, Vol. 12 No. 22, pp. 1-14.

El Hajj, M.C., Abou Moussa, R. and Chidiac, M. (2017), "Environmental sustainability out of the loop in Lebanese universities", Journal of International Education in Business, Vol. 10 No. 1, pp. 49-67.

Elkington, J. (1997), Cannibals with Forks. The Triple Bottom Line of 21st Century Business, Capstone Publishing, Oxford.

Ertmer, P.A., Newby, T.J. and MacDougall, M. (1996), "Students' responses and approaches to casebased instruction: the role of reflective self-regulation", American Educational Research Journal, Vol. 33 No. 3, pp. 719-752.

Farashahi, M. and Tajeddin, M. (2018), "Effectiveness of teaching methods in business education: a comparison study on the learning outcomes of lectures, case studies and simulations", The International Journal of Management Education, Vol. 16 No. 1, pp. 131-142.

Fernando, M., Fox, S., Bandara, R. and Hartley, D. (2020), "Lowering the walls: an integrative approach to first-year undergraduate business education”, Journal of International Education in Business, Vol. 13 No. 2, pp. 275-295.

Friedland, J. and Jain, T. (2020), "Reframing the purpose of business education: crowding-in a culture of moral self-awareness", Journal of Management Inquiry, Vol. 31 No. 1, pp. 1-15.

Garvin, D.A. (2003), "Making the case”, Harvard Magazine, Vol. 106 No. 1, pp. 56-65.

Garvin, D.A. (2007), "Teaching executives and teaching MBAs: reflections on the case method", Academy of Management Learning and Education, Vol. 6 No. 3, pp. 364-374.

Georgallis, P. and Lee, B. (2020), "Toward a theory of entry in moral markets: the role of social movements and organizational identity", Strategic Organization, Vol. 18 No. 1, pp. 50-74.

Georgallis, P., Albino-Pimentel, J. and Kondratenko, N. (2021), "Jurisdiction shopping and foreign location choice: the role of market and nonmarket experience in the European solar energy industry", Journal of International Business Studies, Vol. 52 No. 5, pp. 853-877.

Global Justice Now. (2018), "69 of the richest 100 entities on the planet are corporations, not governments, figures show”, available at: www.globaljustice.org.uk/news/69-richest-100entities-planet-are-corporations-not-governments-figures-show/ (accessed 28 March 2021).

Godemann, J., Herzig, C., Moon, J. and Powell, A. (2011), "Integrating sustainability into business schools analysis of 100 UN PRME sharing information on progress (SIP) reports", available at: https:// citeseerx.ist.psu.edu/viewdoc/download?doi=10.1.1.685.1949\&rep=rep1\&type=pdf (accessed 30 March 2021).

Green, C.S. and Klug, H.G. (1990), "Teaching critical thinking and writing through debates: an experimental evaluation”, Teaching Sociology, Vol. 18 No. 4, pp. 462-471.

Greiner, L.E., Bhambri, A. and Cummings, T.G. (2003), "Searching for a strategy to teach strategy", Academy of Management Learning and Education, Vol. 2 No. 4, pp. 402-420.

Hennessey, J. (2014), "Motivating a productive discussion of normative issues through debates", The Journal of Economic Education, Vol. 45 No. 3, pp. 225-239.

Hoffman, A. (2020), “The University of Michigan endowment fund: divesting from fossil fuels”, William Davidson Institute, available at: https:/wdi-publishing.com/product/the-university-of-michiganendowment-fund-divesting-from-fossil-fuels (accessed 2 February 2021). 
Hoffman, A.J. (2017), "The evolving focus of business sustainability education", EarthEd. State of the World, Island Press, Washington, DC.

Hoffman, A.J. (2018), "The next phase of business sustainability", Stanford Social Innovation Review, Vol. 16 No. 2, pp. 34-39.

Huryn, J.S. (1986), "Debating as a teaching technique”, Teaching Sociology, Vol. 14 No. 4, pp. 266-269.

IPCC. (2021), "Summary for policymakers. In climate change 2021: the physical science basis", available at: www.ipcc.ch/report/ar6/wg1/ (accessed 2 September 2021).

Jack, A. (2020a), "The rise of the "sustainable MBA", available at: www.ft.com/content/2a73f3de-339d11ea-a329-0bcf87a328f2 (accessed 19 March 2021).

Jack, A. (2020b), "Weighing up business schools' work on sustainability", available at: www.ft.com/ content/6b499b5b-76fc-4fee-9684-f8055e52c46e (accessed 19 March 2021).

Kalamas Hedden, M., Worthy, R., Akins, E., Slinger-Friedman, V. and Paul, R.C. (2017), "Teaching sustainability using an active learning constructivist approach: discipline-specific case studies in higher education”, Sustainability, Vol. 9 No. 8, pp. 1-18.

Kearins, K. and Springett, D. (2003), "Educating for sustainability: developing critical skills", Journal of Management Education, Vol. 27 No. 2, pp. 188-204.

Kennedy, R. (2007), "In-class debates: fertile ground for active learning and the cultivation of critical thinking and oral communication skills", International Journal of Teaching and Learning in Higher Education, Vol. 19 No. 2, pp. 183-190.

Klecha, R. (2017), "Business schools step up MBA sustainability focus in response to student demand", available at: www.businessbecause.com/news/online-mba/4694/business-schools-mba-sustainabilityfocus-student-demand (accessed 19 March 2021).

Landrum, N.E. and Ohsowski, B. (2017), "Content trends in sustainable business education: an analysis of introductory courses in the USA", International Journal of Sustainability in Higher Education, Vol. 18 No. 3, pp. 385-414.

Lee, B., Georgallis, P. and Struben, J. (2022), "Sustainable entrepreneurship under market uncertainty: opportunities, challenges, and impact", in George, G., Haas, M., Joshi, H., McGahan, A. and Tracey, P. (Eds), Handbook on the Business of Sustainability: The Organization, Implementation, and Practice of Sustainable Growth, Edward Elgar Publishing, Cheltenham.

Leleux, B. and Van Der Kaaij, J. (2013), "Darwinians at the gate: sustainability, innovation and growth at DSM", Institute for Management Development, available at: https://store.hbr. org/product/darwinians-at-the-gate-sustainability-innovation-and-growth-at-dsm/IMD720 (accessed 2 February 2021).

Lilley, K., Barker, M. and Harris, N. (2014), "Educating global citizens in business schools", Journal of International Education in Business, Vol. 7 No. 1, pp. 72-84.

Pilz, M. and Zenner, L. (2018), "Using case studies in business education to promote networked thinking: findings of an intervention study", Teaching in Higher Education, Vol. 23 No. 3, pp. 325-342.

Pitt-Watson, D. and Quigley, E. (2019), "Business school rankings for the 21st century", UN Principles for Responsible Management Education (PRME), available at: www.abis-global.org/content/ documents/2018/business-school-rankings-for-the-21st-century.pdf (accessed on 25 March 2021).

Porter, M.E. and Kramer, M.R. (2011), "The big idea: creating shared value. How to reinvent capitalism - and unleash a wave of innovation and growth”, Harvard Business Review, Vol. 89, pp. 62-77.

PRME. (2021), "A global movement transforming business and management education through research and leadership", available at: www.unprme.org/ (accessed 29 March 2021).

Radi Afsouran, N., Charkhabi, M., Siadat, S.A., Hoveida, R., Oreyzi, H.R. and Thornton, G.C. III. (2018), "Case-method teaching: advantages and disadvantages in organizational training", Journal of Management Development, Vol. 37 Nos 9/10, pp. 711-720. 
Ray, M. (2018), “Teaching economics using 'cases'-going beyond the 'chalk-and-talk' method”, International Review of Economics Education, Vol. 27, pp. 1-9.

Rodriguez-Dono, A. and Hernández-Fernández, A. (2021), "Fostering sustainability and critical thinking through debate - a case study", Sustainability, Vol. 13 No. 11, p. 6397.

Sandel, M.J. (2013), "Market reasoning as moral reasoning: why economists should re-engage with political philosophy", Journal of Economic Perspectives, Vol. 27 No. 4, pp. 121-140.

Scherer, A.G., Palazzo, G. and Seidl, D. (2013), "Managing legitimacy in complex and heterogeneous environments: sustainable development in a globalized world", Journal of Management Studies, Vol. 50 No. 2, pp. 259-284.

Schroeder, H. and Ebert, D.G. (1983), "Debates as a business and society teaching technique", The Journal of Business Education, Vol. 58 No. 7, pp. 266-269.

Scott, M. (2015), "Sustainability now key selling point for business schools attracting students", available at: www.theguardian.com/sustainable-business/2015/feb/09/are-business-schoolstaking-sustainability-seriously (accessed 19 March 2021).

Shapiro, B.P. (1984), Hints for Case Teaching, Harvard Business School Publishing, Boston, MA.

Springett, D. (2005), "Education for sustainability in the business studies curriculum: a call for a critical agenda", Business Strategy and the Environment, Vol. 14 No. 3, pp. 146-159.

Stewart, K.A. and Winn, J. (1996), "The case debate: a new approach to case teaching”, Journal of Management Education, Vol. 20 No. 1, pp. 48-59.

Van der Byl, C.A. and Slawinski, N. (2015), "Embracing tensions in corporate sustainability: a review of research from win-wins and trade-offs to paradoxes and beyond", Organization and Environment, Vol. 28 No. 1, pp. 54-79, doi: 10.1177/1086026615575047

Vishwanathan, P., van Oosterhout, H., Heugens, P.P., Duran, P. and Van Essen, M. (2020), "Strategic CSR: a concept building meta-analysis", Journal of Management Studies, Vol. 57 No. 2, pp. 314-350, doi: 10.1111/joms.12514.

Vo, H.X. and Morris, R.L. (2006), "Debate as a tool in teaching economics: rationale, technique, and some evidence", Journal of Education for Business, Vol. 81 No. 6, pp. 315-320.

Williams, A., Kennedy, S., Philipp, F. and Whiteman, G. (2017), "Systems thinking: a review of sustainability management research", Journal of Cleaner Production, Vol. 148, pp. 866-881.

Winsted, K. (2010), "Marketing debates: in the classroom and online", Marketing Education Review, Vol. 20 No. 1, pp. $77-82$.

\section{Appendix}

To gauge the use of case-based debates and other teaching methods in sustainability teaching, we performed a content analysis of all the course syllabi available from the Organizations and the Natural Environment Division of the Academy of Management [3] and the Ideas Worth Teaching initiative developed by the Aspen Institute Business and Society program [4] (45 in total). We chose these two sources as they include syllabi from leading courses on the topics of responsible management education and business sustainability.

We perused the syllabi using the following categorization of teaching methods (Brown and Guilding, 1993):

- lectures and tutorials;

- case method;

- simulation;

- field visit or project; 
- role-playing;

- debate; and debates

- case-based debate.

We recorded whether a particular teaching method was mentioned as used in each course.

The results of this content analysis can be found in Figure 1. From the 45 syllabi analyzed, all the courses used either a lecture, tutorial or both. The second most used method was the case method. Other teaching methods such as simulation, field visit or project and role-playing were used to a lesser extent, and, somewhat surprisingly, the debate method was used by only one course. Finally, in line with expectations, none of the syllabi mentioned the use of case-based debates.

\section{Corresponding author}

Panikos Georgallis can be contacted at:p.georgallis@uva.nl

For instructions on how to order reprints of this article, please visit our website: www.emeraldgrouppublishing.com/licensing/reprints.htm Or contact us for further details: permissions@emeraldinsight.com 